\title{
Bioluminescence in the high Arctic during the polar night
}

\author{
J. Berge $\cdot$ A. S. Båtnes $\cdot$ G. Johnsen · \\ S. M. Blackwell • M. A. Moline
}

Received: 8 August 2011/Accepted: 13 September 2011/Published online: 27 September 2011

(C) The Author(s) 2011. This article is published with open access at Springerlink.com

\begin{abstract}
This study examines the composition and activity of the planktonic community during the polar night in the high Arctic Kongsfjord, Svalbard. Our results are the first published evidence of bioluminescence among zooplankton during the Arctic polar night. The observations were collected by a bathyphotometer detecting bioluminescence, integrated into an autonomous underwater vehicle, to determine the concentration and intensity of bioluminescent flashes as a function of time of day and depth. To further understand community dynamics and composition, plankton nets were used to collect organisms passing through the bathyphotometer along with traditional vertical net tows. Additionally, using a moored bathyphotometer closed to the sampling site, the bioluminescence potential itself was shown not to have a diurnal or circadian rhythm. Rather, our results provide evidence for a diel vertical migration of bioluminescent zooplankton that does
\end{abstract}

Communicated by U. Sommer.

J. Berge $(\bowtie) \cdot$ A. S. Båtnes · G. Johnsen

University Centre on Svalbard, PB 156,

9171 Longyearbyen, Norway

e-mail: Jorgen.berge@unis.no

J. Berge

Faculty of Biosciences, Fisheries and Economics,

University of Troms $\varnothing, 9037$ Tromsö, Norway

A. S. Båtnes - G. Johnsen

Department of Biology, Norwegian University of Science

and Technology, 7491 Trondheim, Norway

S. M. Blackwell · M. A. Moline

Department of Biological Sciences, Center for Coastal Marine

Sciences, California Polytechnic State University,

San Luis Obispo, CA 93407, USA not correspond to any externally detectable changes in illumination.

\section{Introduction}

Of the various behaviors and adaptations that have evolved in marine environments, bioluminescence stands out as one of the particular importance, given the fact that it has evolved independently more than 40 times (Haddock et al. 2010). While it does not necessarily give specific advantage to species in cold environments, the long periods of continuous darkness that characterize winters at high latitudes create an environment, at least with respect to light, that is similar to the deep-sea. Depending on which taxa are bioluminescent, a variety of adaptive advantages have been suggested. These include defensive functions such as the "counter-illumination," the "burglar alarm" and offensive mechanisms such as "prey attraction" and "intraspecific communication" (Haddock et al. 2010).

Other adaptations have evolved in both phytoplankton and zooplankton to survive in these harsh conditions that relate more to metabolic rates and the actual vertical space occupied in the water column within which a species spends the winter months. One such strategy is to enter a dormant state and overwinter at depth, seen for the copepods Calanus glacialis and $C$. hyperboreus which are commonly reported to enter a state of diapause at depth during winter months (Fortier et al. 2001; Falk-Petersen et al. 2008). They, then, return to shallower water in the summer to take advantage of the high productivity rates (Ashjian et al. 2003). Interestingly, Berge et al. (2009) for the first time provide acoustic evidence of active vertical migrations of zooplankton throughout the polar night in the high Arctic. More recently, this phenomenon was 
corroborated in the Southern Hemisphere where diel vertical migration (DVM) was shown to continue through the Austral winter in the Lazarev Sea, but ceased during the Austral summer (Cisewski et al. 2010).

The goal of the current study was to characterize plankton abundance and distribution patterns during a time of year that has rarely been studied by means of vertical net tows and autonomous underwater vehicle (AUV) surveys. Fitted on the AUV were ADCPs, a CTD and a bathyphotometer designed to register bioluminescence potential in the water column.

\section{Materials and methods}

Data were collected off the coast of $\mathrm{Ny}$ Allesund in Kongsfjord, Svalbard $\left(78^{\circ} 57^{\prime} \mathrm{N}, 11^{\circ} 56^{\prime} \mathrm{E}\right)$ in $\sim 120 \mathrm{~m}$ of water from January 19 to 22, 2010. Spatial and temporal dynamics of acoustic backscatter, salinity, temperature and bioluminescence were measured using a REMUS-100 AUV (Moline et al. 2005). The vehicle was equipped with upward and downward facing RD Instruments $1,200-\mathrm{kHz}$ Workhorse navigator acoustic Doppler current profilers (ADCP), configured in this study to provide relative acoustic backscatter as an estimate of scattering volume, rather than current velocities, a Neil-Brown CTD and a bioluminescence bathyphotometer (BP; Moline et al. 2005). The BP utilizes an impeller to continuously draw a measured volume of water into a chamber through the front of the nosecone where bioluminescence is measured by a photomultiplier tube at $60 \mathrm{~Hz}$ [see Herren et al. (2005) for details]. For statistical purposes, we restricted our analysis to the non-zero observations.

The AUV was deployed at 10:27, 12:25 and at 13:40 (local time 19th of January) at depths of 15, 45 and $75 \mathrm{~m}$, respectively. These missions were surveyed a transect of $1.5 \mathrm{~km}$ at each respective depth. The vehicle was also deployed at 21:30 (19th of January) along the same transect as during the "day" but ran one mission surveying the transect at 15, 45 and $75 \mathrm{~m}$ successively without breaks between each depth. ADCP data were processed to remove noise and calculate relative backscatter coefficient $\left(S_{\mathrm{v}}\right)$ according to Deines (1999) for the data collected between 0.5 and $5.0 \mathrm{~m}$ away from either side of the vehicle. Following the AUV deployments, continuous BP observations were made from 15:00 on January 21, 2010 until 09:00 on January 22, 2010 at $1 \mathrm{~m}$ depth at the Ny Alesund harbor about $2 \mathrm{~km}$ from the study site. For logistical reasons (power supply, stable holdfast for the instrument and weather conditions), it was not possible to carry out the continuous BP observations in the fjord at the same place as the AUV deployments. However, given the short distance between the two locations and the absence of any physical barriers, the two sites are regarded as comparable for the examination of circadian rhythm (see also "Discussion"). Concurrent with the REMUS deployments, vertical net hauls were conducted using a WP2 plankton net, $180-\mu \mathrm{m}$ mesh size with a $0.25 \mathrm{~m}^{2}$ opening. In order to collect vertical net hauls from the same depths surveyed by the REMUS ADCP, two replicates from each depth were taken from $30-0 \mathrm{~m}, 60-0 \mathrm{~m}$ and from $90-0 \mathrm{~m}$ between 10:30-13:00 LT. During the nighttime AUV deployment, replicate hauls were taken between $30-0 \mathrm{~m}$, but inclement weather resulted in only one sample from $60-0 \mathrm{~m}$ was collected and none between $90-0 \mathrm{~m}$. To determine species composition and abundance for specific depth intervals of $60-30 \mathrm{~m}$ and $90-60 \mathrm{~m}$, the results from $30-0 \mathrm{~m}$ were subtracted from those of $60-0 \mathrm{~m}$, and results from $60-0 \mathrm{~m}$ from those of $90-0 \mathrm{~m}$, respectively. Additionally, the REMUS BP was equipped with cylindrical plankton nets (20- $\mu \mathrm{m}$ mesh size), and these nets were fitted to each of the two exhausts of the BP (Moline et al. 2009), which hence provided two replicate samples from each of the depths $(15,45$ and $75 \mathrm{~m})$ sampled using the AUV. For all plankton samples, the nets were rinsed and samples collected and preserved in a $4 \%$ formaldehyde solution. Samples were later enumerated and identified to the lowest possible taxonomic unit using a Leica stereomicroscope with $6.3-40 \times$ magnification.

\section{Results}

The temperature, salinity and density profiles were similar between night and day during the sample period (Fig. 1) and did hence not reveal any major advection events that would otherwise influence the measurements and results presented below. Based upon Willis et al. (2006), physical parameters indicated that the water mass in Kongsfjord was of Artic Water origin. Bioluminescence was detected throughout the water column both night and day, with higher bioluminescence at depth during the day and increased surface bioluminscence at night (Fig. 1d). Comparison of the bioluminescence at the specific depths also provided that this result with significantly greater bioluminescence intensity per flash was observed at $75 \mathrm{~m}$ during the day and at $15 \mathrm{~m}$ at night (Table 1), suggesting that the organisms with more intense flashes, i.e., larger zooplankton (see Moline et al. 2009), had migrated toward shallower depths at night.

It is important when interpreting changes in bioluminescence signals that the circadian rhythms in the bioluminescence potential of planktonic organisms be taken into account (Batchelder et al. 1992). The continuous BP observations at the Ny Alesund harbor showed no evidence of a circadian rhythm in the bioluminescence signal 

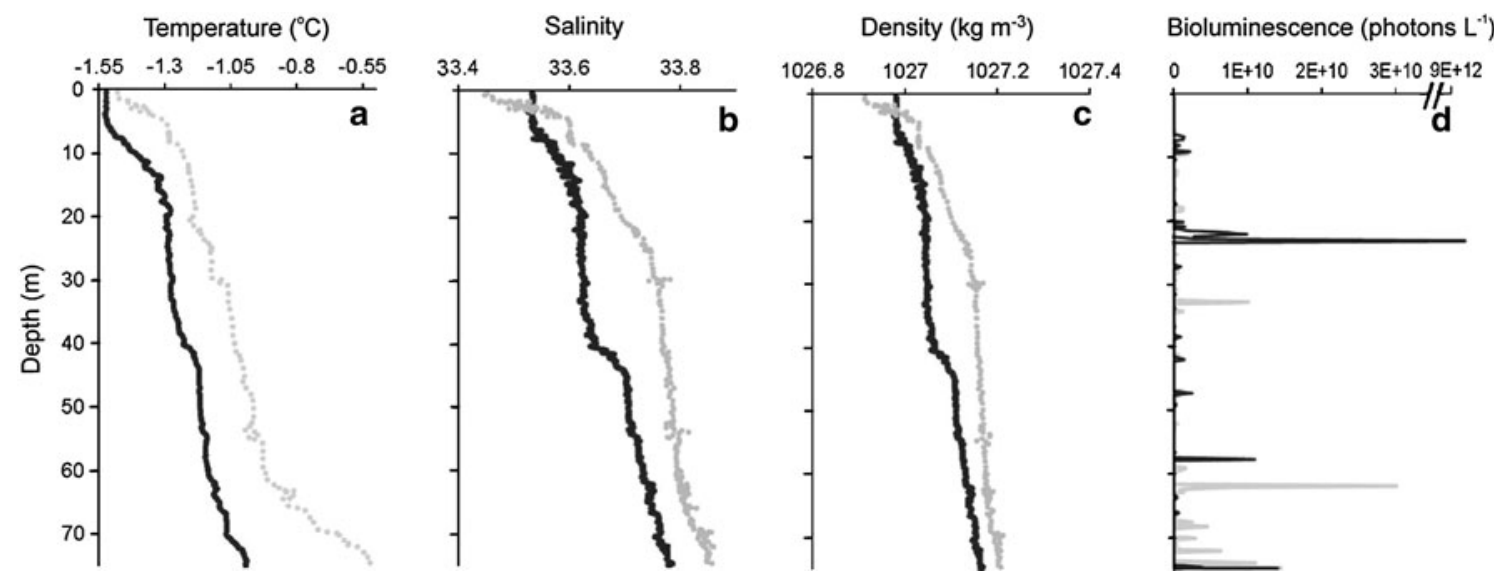

Fig. 1 Vertical profiles of a temperature $\left({ }^{\circ} \mathrm{C}\right)$, b salinity (ppt), $\mathbf{c}$ density $\left(\mathrm{kg} \mathrm{m}^{-3}\right)$ and $\mathbf{d}$ bioluminescence (photons/l) as a function of depth (m) taken from the REMUS AUV during the final ascents from $75 \mathrm{~m}$ during the day and night deployments. Daytime observations represented in gray and nighttime in black. For this profile,

(Fig. 2) in a location (sheltered by the pier and with a max depth of $5 \mathrm{~m}$ ) where vertical migration of zooplankton would be restricted. Organisms collected by net hauls next to the moored BP and by nets connected to the BP during this period using identical methods described above for the AUV showed $>80 \%$ similarity to the study transects (data not shown), thus making these results applicable to the observations made by the AUV.

Estimates of relative backscatter coefficient as a relative measure of zooplankton biomass in a 10-m swath around the prescribed vehicle depths showed significantly higher intensity between 70 and $80 \mathrm{~m}$ during the day, and between 10 and $20 \mathrm{~m}$ and $40-50 \mathrm{~m}$ at night (Table 1). In combination with the changes in bioluminescence intensity, these data demonstrated a coordinated movement of biomass indicative of DVM.

Plankton enumerations from WP2 vertical net hauls show an increase above $60 \mathrm{~m}$ in the majority of the most abundant zooplankton taxa at night, including Pseudocalanus spp., Microcalanus spp., Oithona spp., Calanus spp., Metridia spp. and Thysanoessa spp. These genera have

bioluminescence for the upper water column $(<45 \mathrm{~m})$ was significantly less than that for the lower water column during the day (Mann-Whitney, $P=0.009, n=102$ ) and higher bioluminescence in the upper water column at night

been reported to present throughout the year in this regions (Lischka and Hagen 2005). Table 2 provides specific species classification and shows that this increase above $60 \mathrm{~m}$ at night is also apparent in the enumerations of other less abundant taxa including Calanus finmarchicus, Acartia longiremis, Oncaea borealis and Eukrohnia hamata. Of these, Metridia lucens, Metridia longa, Oncaea borealis, Thysanoessa inermis and Thysanoessa longicaudata most likely account for the increase in high-intensity bioluminescent flashes at 15 and $45 \mathrm{~m}$ during the night (Table 1).

Plankton enumerated from the $>20 \mu \mathrm{m}$ net collection of the BP exhaust suggests that during the day, the greatest biomass occurred at $45 \mathrm{~m}$ and was dominated by copepod nauplii, copepod eggs and the Tintinnid Acantostomella norvegica (Table 3 ). The same three groups of organisms dominated the biomass at 15 and $75 \mathrm{~m}$. Other major contributors at each of these three depths were Ceratium and Protoperidinium spp., Salpingella acuminata Pseudocalanus spp., Microcalanus spp., Oithona similis and Oithona atlantica (Table 3), consistent with the WP2 nets samples (Table 2).

Table 1 Mean Bioluminescence intensity per flash $( \pm$ SE) surveyed by the AUV at the three different depths during the daytime and nighttime deployments (LT is local time)

\begin{tabular}{llcl}
\hline Depth $(\mathrm{m})$ & $\begin{array}{l}\text { Mean intensity/flash } \\
\left(\times 10^{8}\right) \text { daytime } \\
(10: 30-14: \times 25 \mathrm{LT})\end{array}$ & $\begin{array}{l}\text { Mean intensity/flash } \\
\left(\times 10^{8}\right) \text { daytime } \\
(21: 30-22: 30 \mathrm{LT})\end{array}$ & $\begin{array}{l}\text { Mean } S_{\mathrm{v}} \text { difference } \\
(\text { day-night })\end{array}$ \\
\hline 15 & $9 \pm 2^{*}$ & $160 \pm 142^{\dagger}$ & -16 \\
45 & $7 \pm 2$ & $8 \pm 3$ & -35 \\
75 & $18 \pm 6^{* \dagger}$ & $4 \pm 1^{\dagger+}$ & 17 \\
\hline
\end{tabular}

Significant differences were found between depths using Mann-Whitney $\left({ }^{*} P=0.016, n=1,030 ;{ }^{\dagger} P=0.025, n=286 ;{ }^{*} P=0.022\right.$, $n=126)$, and additionally, the difference in the mean acoustic backscatter coefficients $\left(S_{\mathrm{v}}\right)$ between day and night is shown for each depth. The differences in $S_{\mathrm{v}}$ between day and night were significant (Mann-Whitney, $P<0.001$ ) at all depths 


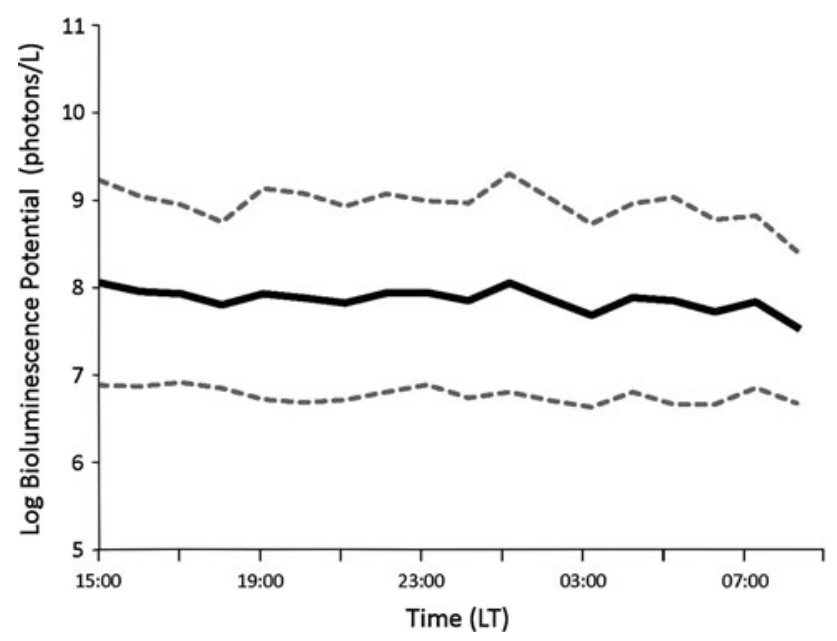

Fig. 2 Hourly means of log bioluminescence potential (solid black line) with standard deviations (dotted black lines) collected at $1 \mathrm{~m}$ depth from 15:00 LT on January 21 to 09:00 LT on January 22, 2010, ( $n=9,545$, non-zero observations). Flashes per unit time were also found to be consistent throughout the time series

Evident from organisms collected from both net sampling approaches is that the day/night changes in the vertical distributions of bioluminescence and acoustic scattering resulted from the larger zooplankton. Zooplankton taxa $>2.3 \mathrm{~mm}$ (Calanus spp., Metridia spp., Thysanoessa spp. and Appendicularia) collected by the WP2 vertical net tows showed decreased abundance at the surface (upper two depth layers) during the day than during the night and the highest abundance of this size class was found at depth during the day (Table 2). The smaller size class (Pseudocalanus spp, Microcalanus spp., Oithona spp.) did not show this trend. Histograms of the bioluminescence intensity (data not shown) in conjunction with plankton enumerations from each depth suggest that an underlying low-to-intermediate-intensity bioluminescence was consistent between day and night and likely attributed to the dinoflagellates, from Protoperidinium that occurred throughout the water column and to a lesser degree, Ceratium furca and $C$. fusus that were present in significantly lower abundances (Table 3).

\section{Discussion}

Though ubiquitous in the world's oceans and important from an ecological and evolutionary perspective (for review see Haddock et al. 2010), few studies have described bioluminescent communities and their distributions in the Arctic, particularly during the winter darkness. Buskey (1992), and Lapota et al. (1989, 1992) examined bioluminescence distributions and community structure with the goal of developing methodology to use bioluminescence as a way to measure total biomass and light budgets of a given water mass during the spring in the Greenland Sea, during the fall in the Beaufort Sea and in summer in a Norwegian Fjord, respectively. In contrast, this study quantified the bioluminescent community during the polar night and demonstrated the absence of circadian rhythm in bioluminescence.

Furthermore, both the diurnal distribution of bioluminescence intensity and concurrent changes in acoustic backscattering provide independent evidence for an active DVM of the larger bioluminescent zooplankton (and likely non-bioluminescent zooplankton) within the upper $75 \mathrm{~m}$ of the water column. Histograms of intensities showed the major differences between day and night occurring at the highest intensities, which is consistent with larger zooplankton (Lapota et al. 1992; Moline et al. 2009) and with the enumerations in this study. Bioluminscence and acoustic backscatting may in fact not be directly linked, but the circumstantial evidence provided herein suggests that the diurnal signal in bioluminescence is in fact caused by vertically migrating organisms. Numerous studies have examined proximal triggers for DVM (Forward 1988; Ringelberg 1995; Ringelberg and Van Gool 2003; Benoit-Bird et al. 2009), and many others have looked at triggers for the inhibition of bioluminescence as related to its circadian rhythm (Batchelder et al. 1992; Kelly and Katona 1966; Raymond and DeVries 1976; Swift et al. 1995). Interestingly all studies have in one way or another implicated a relative or absolute change in irradiance intensity, angle or daylength as a means of regulation for both DVM and the circadian rhythm of bioluminescence. Although changes in light during the time of this study are not visible to the human eye, it is possible that they were sufficient to initiate DVM in the organisms present at the time of the study as was suggested in the study by Berge et al. (2009). However, while external light cues may play a role in regulating DVM, it might not be the only factor relevant to consider for understanding this behavior. It has been well established for photosynthetic dinoflagellates and for heterotrophic dinoflagellates of the Protoperidinium genus that the bioluminescent inhibition occurs when light intensities are greater than the intensity of bioluminescence of the organisms themselves (Sweeney et al. 1959; Buskey et al. 1992). This phenomenon could explain why no circadian rhythm existed in bioluminescence during December and January in Antarctica (Raymond and DeVries 1976) and may also be related to the absence of a circadian rhythm in bioluminescence in the current study. Previous studies have found that Protoperidinium spp contributed between 20 and $90 \%$ of the total light budget from the surface to a depth of $100 \mathrm{~m}$ in the Beaufort Sea (Lapota et al. 1992) and that dinoflagellates were estimated to account for $96 \%$ of the total light budget in Vestfjord, 
Table 2 Concentrations of the plankton captured by the $180 \mu \mathrm{m}$ WP2 plankton net during the day and at night for depth intervals $30-0,60-30$ and $90-60 \mathrm{~m}$

\begin{tabular}{|c|c|c|c|c|c|c|c|}
\hline Taxa & $\begin{array}{l}\text { Depth } \\
(\mathrm{m})\end{array}$ & $\begin{array}{l}\text { ind./m } \mathrm{m}^{3} \\
\text { (day) }\end{array}$ & $\begin{array}{l}\text { ind./m }{ }^{3} \\
\text { (night) }\end{array}$ & Taxa & $\begin{array}{l}\text { Depth } \\
(\mathrm{m})\end{array}$ & $\begin{array}{l}\text { ind. } / \mathrm{m}^{3} \\
\text { (day) }\end{array}$ & $\begin{array}{l}\text { ind. } / \mathrm{m}^{3} \\
\text { (night) }\end{array}$ \\
\hline \multirow[t]{3}{*}{ Calanus finmarchicus } & $0-30$ & 50 & 82 & Heterorhabdus norvegicus* & $0-30$ & $<1$ & $<1$ \\
\hline & $30-60$ & 41 & 148 & & $30-60$ & $<1$ & 6 \\
\hline & $60-90$ & 89 & - & & $60-90$ & 4 & - \\
\hline \multirow[t]{3}{*}{ Calanus glacialis } & $0-30$ & 4 & 10 & Harpacticus chelifer & $0-30$ & 9 & 50 \\
\hline & $30-60$ & 31 & 31 & & $30-60$ & 54 & 30 \\
\hline & $60-90$ & 147 & - & & $60-90$ & $<1$ & - \\
\hline \multirow[t]{3}{*}{ Calanus hyperboreus } & $0-30$ & $<1$ & 1 & Harpacticoida spp. & $0-30$ & 2 & $<1$ \\
\hline & $30-60$ & $<1$ & $<1$ & & $30-60$ & 11 & $<1$ \\
\hline & $60-90$ & 4 & - & & $60-90$ & $<1$ & \\
\hline \multirow[t]{3}{*}{ Pseudocalanus spp. } & $0-30$ & 3,100 & 10,300 & Oithona atlantica & $0-30$ & 388 & 725 \\
\hline & $30-60$ & $<1$ & 16,820 & & $30-60$ & $<1$ & 555 \\
\hline & $60-90$ & 775 & - & & $60-90$ & $<1$ & - \\
\hline \multirow[t]{3}{*}{ Microcalanus spp. } & $0-30$ & 563 & 2,300 & Oithona similis & $0-30$ & 400 & 825 \\
\hline & $30-60$ & 163 & 1,900 & & $30-60$ & $<1$ & 1,335 \\
\hline & $60-90$ & 63 & - & & $60-90$ & 131 & - \\
\hline \multirow[t]{3}{*}{ Metridia lucens* } & $0-30$ & 3 & 17 & Appendicularia* & $0-30$ & 17 & 15 \\
\hline & $30-60$ & 4 & 18 & & $30-60$ & 3 & 3 \\
\hline & $60-90$ & 6 & - & & $60-90$ & 96 & - \\
\hline \multirow[t]{3}{*}{ Metridia longa* } & $0-30$ & $<1$ & $<1$ & Limacina helicina & $0-30$ & 2 & $<1$ \\
\hline & $30-60$ & $<1$ & 3 & & $30-60$ & $<1$ & 1 \\
\hline & $60-90$ & 11 & - & & $60-90$ & 12 & - \\
\hline \multirow[t]{3}{*}{ Acartia longiremis } & $0-30$ & 175 & 375 & Sagitta elegans & $0-30$ & $<1$ & 2 \\
\hline & $30-60$ & $<1$ & 385 & & $30-60$ & 5 & 11 \\
\hline & $60-90$ & $<1$ & - & & $60-90$ & 12 & - \\
\hline \multirow[t]{3}{*}{ Paraeuchaeta norvegica } & $0-30$ & $<1$ & $<1$ & Eukrohnia hamata & $0-30$ & 4 & 30 \\
\hline & $30-60$ & 1 & $<1$ & & $30-60$ & 2 & 21 \\
\hline & $60-90$ & $<1$ & - & & $60-90$ & 11 & - \\
\hline \multirow[t]{3}{*}{ Diastylis lucifera* } & $0-30$ & $<1$ & $<1$ & Thysanoessa longicaudata* & $0-30$ & $<1$ & 2 \\
\hline & $30-60$ & 1 & $<1$ & & $30-60$ & 3 & 7 \\
\hline & $60-90$ & $<1$ & - & & $60-90$ & 2 & - \\
\hline \multirow[t]{3}{*}{ Bradyidius similis } & $0-30$ & $<1$ & 1 & Thysanoessa inermis* & $0-30$ & $<1$ & $<1$ \\
\hline & $30-60$ & $<1$ & 3 & & $30-60$ & $<1$ & 22 \\
\hline & $60-90$ & 6 & - & & $60-90$ & $<1$ & - \\
\hline \multirow[t]{3}{*}{ Oncaea borealis* } & $0-30$ & 12 & $<1$ & & & & \\
\hline & $30-60$ & 51 & 200 & & & & \\
\hline & $60-90$ & $<1$ & - & & & & \\
\hline
\end{tabular}

Asterisks indicate organisms known to be bioluminescent

Norway (Lapota et al. 1989), so it is reasonable to assume that they were significant contributors to the overall light budget during this study. Wherein the lack of sunlight facilitated an environment where the intensity of bioluminescence was not inhibited by light greater than the bioluminescence of the organisms themselves. While this regulatory factor has been established for dinoflagellates, it is possible that it plays a role in other bioluminescent taxa as well, such as copepods, appendicularians and Arctic krill as in the case of this study.

\section{Conclusions and perspectives}

The most notable finding in this study is the detection of bioluminescent activity among zooplankton during the 
Table 3 Concentrations of the plankton captured by the $20 \mu \mathrm{m}$ plankton nets covering the REMUS BP exhaust for daytime deployments at 15,45 and $75 \mathrm{~m}$

\begin{tabular}{|c|c|c|c|c|c|}
\hline Taxa & Depth (m) & ind $/ \mathrm{m}^{3}$ & Taxa & Depth (m) & $\mathrm{ind} / \mathrm{m}^{3}$ \\
\hline \multirow[t]{3}{*}{ Ceratium arcticum } & 15 & 229 & \multirow[t]{3}{*}{ Copepod nauplii* } & 15 & 1,409 \\
\hline & 45 & 352 & & 45 & 2,726 \\
\hline & 75 & 246 & & 75 & 1,403 \\
\hline \multirow[t]{3}{*}{ Ceratium fusus* } & 15 & 9.6 & \multirow[t]{3}{*}{ Copepod eggs } & 15 & 903 \\
\hline & 45 & 91.3 & & 45 & 1,631 \\
\hline & 75 & 80.3 & & 75 & 1,372 \\
\hline \multirow[t]{3}{*}{ Ceratium furca } & 15 & $<1$ & \multirow[t]{3}{*}{ Oncaea borealis* } & 15 & 5 \\
\hline & 45 & 13 & & 45 & 52 \\
\hline & 75 & 4 & & 75 & 4 \\
\hline \multirow[t]{3}{*}{ Protoperidinium spp.* } & 15 & 211 & Harpacticoida spp. & 15 & 7 \\
\hline & 45 & 391 & \multirow[t]{5}{*}{ Microsetella norvegica } & 45 & 7 \\
\hline & 75 & 387 & & 75 & 4 \\
\hline \multirow[t]{3}{*}{ Diatom spp. } & 15 & 10 & & 15 & 5 \\
\hline & 45 & 59 & & 45 & 7 \\
\hline & 75 & 80 & & 75 & 4 \\
\hline \multirow[t]{3}{*}{ Acantostomella norvegica } & 15 & 1,252 & \multirow[t]{3}{*}{ Oithona atlantica } & 15 & 67 \\
\hline & 45 & 2,023 & & 45 & 117 \\
\hline & 75 & 827 & & 75 & 59 \\
\hline \multirow[t]{3}{*}{ Salpingella acuminata } & 15 & 241 & \multirow[t]{3}{*}{ Oithona similis } & 15 & 72 \\
\hline & 45 & 163 & & 45 & 111 \\
\hline & 75 & 122 & & 75 & 108 \\
\hline \multirow[t]{3}{*}{ Heliocostomella subulata } & 15 & 2 & \multirow[t]{3}{*}{ Eukrohnia hamata } & 15 & $<1$ \\
\hline & 45 & 13 & & 45 & 1 \\
\hline & 75 & $<1$ & & 75 & $<1$ \\
\hline \multirow[t]{3}{*}{ Parafavella denticulata } & 15 & 7 & \multirow[t]{3}{*}{ Gastropoda larvae } & 15 & 23 \\
\hline & 45 & 33 & & 45 & 33 \\
\hline & 75 & 45 & & 75 & 11 \\
\hline \multirow[t]{3}{*}{ Calanus finmarchicus } & 15 & 8 & \multirow[t]{3}{*}{ Appendicularia* } & 15 & 11 \\
\hline & 45 & 8 & & 45 & 39 \\
\hline & 75 & 11 & & 75 & 21 \\
\hline \multirow[t]{3}{*}{ Paraeuchaeta norvegica CIII } & 15 & $<1$ & \multirow[t]{3}{*}{ Membranipora larvae } & 15 & 19 \\
\hline & 45 & 1 & & 45 & 20 \\
\hline & 75 & $<1$ & & 75 & 21 \\
\hline \multirow[t]{3}{*}{ Acartia longiremis } & 15 & 29 & \multirow[t]{3}{*}{ Bivalve larvae } & 15 & $<1$ \\
\hline & 45 & 7 & & 45 & 7 \\
\hline & 75 & 18 & & 75 & $<1$ \\
\hline \multirow[t]{3}{*}{ Pseudocalanus spp. } & 15 & 205 & \multirow[t]{3}{*}{ Limacina helicina } & 15 & $<1$ \\
\hline & 45 & 215 & & 45 & $<1$ \\
\hline & 75 & 154 & & 75 & 4 \\
\hline Microcalanus spp. & 15 & 137 & Thysanoessa longicaudata* & 15 & $<1$ \\
\hline & 45 & 437 & & 45 & $<1$ \\
\hline & 75 & 140 & & 75 & 1 \\
\hline
\end{tabular}

polar night, which may be an important ecological feature. While the ultimate and proximate explanations for both the bioluminescence and the DVM behavior detected during the campaign fall outside the data collected during this study, these results provide evidence for both endogenous and exogenous control of poorly understood or previously unknown processes. Also, during this expedition, which took place during the darkest period of the polar night, we observed five different species of seabirds actively foraging at sea; little auk (Alle alle), black-legged kittiwake (Rissa tridactyla), northern fulmar (Fulmarus glacialis), black guillemot (Cepphus grylle) and brünnich's guillemot (Uria 
lomvia). These seabirds have, to the best of our knowledge, not been reported to overwinter at these latitudes. Whether bioluminescence and/or DVM are playing roles in the foraging behavior of these visual predators is an exciting possibility, although still an open question. Despite the limited scope of this study, results open new lines of enquiry regarding the function and process during a time of year when classical paradigms of Arctic ecosystems postulate that organisms are predominately in a state of hibernation (see Berge et al. 2009). Ultimately, these questions also have implications for human activities (i.e., oil exploration) in the high Arctic, which up until to now has been considered "without life" during the polar night.

Open Access This article is distributed under the terms of the Creative Commons Attribution Noncommercial License which permits any noncommercial use, distribution, and reproduction in any medium, provided the original author(s) and source are credited.

\section{References}

Ashjian CJ, Campbell RG, Welch HE, Butler M, Van Keuren D (2003) Annual cycle in abundance, distribution, and size in relation to hydrography of important copepod species in the western Arctic Ocean. Deep-Sea Res I 50:1235-1261

Batchelder HP, Swift E, Van Keuren R (1992) Diel patterns of plankton bioluminescence in the northern Sargasso Sea. Mar Biol 113:329-339

Benoit-Bird K, Au WWL, Wisdon DW (2009) Nocturnal light and lunar cycle effects on diel migration of micronekton. Limnol Oceanogr 54:1789-1800

Berge J, Cottier F, Last KS, Varpe Ø, Leu E, Søreide J, Eiane K, FalkPetersen S, Willis K, Nygård H, Vogedes D, Griffiths C, Johnsen G, Lorentzen D, Brierley AS (2009) Diel vertical migration of Arctic zooplankton during the polar night. Biol Lett 5:69-72

Buskey EJ (1992) Epipelagic bioluminescence in the marginal ice zone of the Greenland Sea. Mar Biol 113:689-698

Buskey EJ, Strom SL, Coulter CJ (1992) Bioluminescence of heterotrophic dinoflagellates from Texas coastal waters. J Exp Mar Biol Ecol 159:37-49

Cisewski B, Strass VH, Rhein M, Kragefsky S (2010) Seasonal variation of diel vertical migration of zooplankton from ADCP backscatter time series data in the Lazarev Sea, Antarctica. Deep-Sea Res I 57:78-94

Deines KL (1999) Backscatter estimation using broadband acoustic Doppler current profilers. In: Proceedings of IEEE 6th conference on current measurement. 249-253

Falk-Petersen S, Leu E, Berge J, Kwasniewski S, Nygard H, Rostad A, Keskinen E, Thormar J, von Quillfeldt C, Wold A, Gulliksen
B (2008) Vertical migration in high Arctic waters during autumn 2004. Deep-Sea Res II 55:2275-2284

Fortier M, Fortier L, Hattori H, Saito H, Legendre L (2001) Visual predators and the diel vertical migration of copepods under Arctic sea ice during the midnight sun. J Plankton Res 23:1263-1278

Forward RB (1988) Diel vertical migration: zooplankton photobiology and behavior. Oceangr Mar Bio Ann Rev 26:361-393

Haddock SHD, Moline MA, Case JF (2010) Bioluminescence in the Sea. Annu Rev Mar Sci 2:443-493

Herren CM, Haddock SHD, Johnson C, Moline MA, Case JF (2005) A multi-platform bathyphotometer for fine-scale, coastal bioluminescence research. Limnol Oceanogr Methods 3:247-262

Kelly MG, Katona S (1966) An endogenous diurnal rhythm of bioluminescence in a natural population of dinoflagellates. Biol Bull 131:115-126

Lapota D, Geiger ML, Stiffey AV, Rosenberger DE, Young DK (1989) Correlations of planktonic bioluminescence with other oceanographic parameters from a Norwegian fjord. Mar Ecol Prog Ser 55:217-227

Lapota D, Rosenberger DE, Liebermann SH (1992) Planktonic bioluminescence in the pack ice and the marginal ice zone of the Beaufort Sea. Mar Biol 112:665-675

Lischka S, Hagen W (2005) Life histories of the copepods Psuedocalanus minutus, P. acuspes (Calanoida) and Oithona similis (Cyclopoida) in the Arctic Kongsfjorden (Svalbard). Polar Biol 28:910-921

Moline MA, Blackwell SM, von Alt C, Allen B, Austin T, Case J, Forrester N, Goldsborough R, Purcell M, Stokey R (2005) Remote environmental monitoring units: an autonomous vehicle for characterizing coastal environments. J Atm Ocean Tech 22:1797-1808

Moline MA, Blackwell SM, Case JF, Haddock SHD, Herren CM, Orrico CM, Terrill E (2009) Bioluminescence to reveal structure and interaction of coastal planktonic communities. Deep-Sea Res II 56:232-245

Raymond JA, DeVries AL (1976) Bioluminescence in McMurdo Sound, Antarctica. Limnol Oceanogr 21:599-602

Ringelberg J (1995) Changes in light intensity and diel vertical migration: a comparison of marine and freshwater environments. J Mar Biol Assoc UK 28:99-113

Ringelberg J, Van Gool E (2003) On the combined analysis of proximate and ultimate aspects in diel vertical migration (DVM) research. Hydrobiologia 491:85-90

Sweeney BM, Haxo FT, Hasting JW (1959) Action spectra for two effects of light on luminescence in Gonyaulax polyedra. J Gen Physiol 43:285-299

Swift E, Sullivan JM, Batchelder HP, Van Keuren J, Vaillancourt RD, Bidigare RR (1995) Bioluminescent organisms and bioluminescence measurements in the North Atlantic Ocean near latitude 59.5 N, longitude 21 W. J Geophys Res 100:6527-6547

Willis K, Cottier F, Kwasniewski S, Falk-Petersen S (2006) The influence of advection on zooplankton community composition in an Arctic fjord (Kongsfjorden, Svalbard). J Mar Syst 61:39-54 